Ks. Janusz Bujak ${ }^{*}$

Uniwersytet Szczeciński

\title{
HISTORYCZNE I DUCHOWE ASPEKTY CELIBATU W KOŚCIELE
}

Stowa klucze:

czystość, celibat

Treść:

I. Pochodzenie celibatu duchownych: dwie opinie

1. Prawo kościelne u źródeł celibatu duchownych

2. Apostolskie pochodzenie celibatu duchownych

II. Możliwości owocnego przeżywania celibatu

1. Opinie psychiatrów

2. Wartość celibatu w ocenie teologów

Celem artykułu jest przedstawienie dwóch poglądów na pochodzenie celibatu duchownych w Kościele katolickim: jednego, zgodnie z którym celibat to prawo kościelne, dyscyplina dotycząca jedynie Kościoła łacińskiego, i drugiego, zgodnie z którym ma on pochodzenie boskie, źródłem tego stylu życia jest sam Jezus Chrystus i Jego uczniowie. W drugiej części artykułu zostaną przedstawione wybrane opinie psychiatrów i teologów na temat możliwości dojrzałego przeżywania celibatu kapłańskiego.

\section{POCHODZENIE CELIBATU DUCHOWNYCH: DWIE OPINIE}

Od końca XIX wieku trwa gorąca dyskusja na temat celibatu kapłańskiego, w której przewagę uzyskała teza Franza Xaviera Funka, że obowiązek celibatu w Kościele zachodnim został wprowadzony dopiero w IV wieku. Po Soborze Watykańskim II ataki na celibat duchownych jeszcze się

* Ks. Janusz Bujak, dr hab. teologii, prof. Uniwersytetu Szczecińskiego, wykładowca w Koszalinie w Seminarium Duchownym i w Instytucie Teologicznym dla świeckich, diecezjalny referent ds. ekumenizmu w diecezji koszalińsko-kołobrzeskiej. 
wzmogły $^{1}$. Dziś wielu teologów twierdzi, że ten styl życia jest szkodliwy, zbyteczny i należy odejść od obowiązkowego bezżeństwa na rzecz dobrowolnej decyzji kandydatów do święceń wyższych w tym względzie. Miałoby się to przyczynić m.in. do wzrostu powołan, ożywienia dialogu ekumenicznego, likwidacji takich problemów jak pedofilia.

Od wieków też trwa dyskusja, czy obowiązek zachowania celibatu przez duchownych wyższych stopni pochodzi z prawa kościelnego czy też jest on pochodzenia biblijnego.

\section{Prawo kościelne u źródeł celibatu duchownych}

Zwolennicy pierwszego poglądu twierdzą, że w początkowym okresie dziejów Kościoła celibat nie był obowiązkowy i dopiero w IV wieku pojawiły się pierwsze przepisy prawne na ten temat. $Z$ tego powodu należy uznać, że celibat duchownych ma swoje źródło w prawie kościelnym, a zatem nie pochodzi z prawa boskiego.

Wydaje się, że tak właśnie naucza Urząd Nauczycielski Kościoła, np. Sobór Watykański II w dekrecie Presbyterorum ordinis, gdzie czytamy, że „doskonała i dozgonna powściagliwość, zalecana przez Chrystusa Pana ze względu na Królestwo niebieskie [...] nie jest wymagana jednak przez kapłaństwo z jego natury"”2.

Również papież Paweł VI w encyklice Sacerdotalis caelibatus napisał, cytując Presbyterorum ordinis 16: „W rzeczywistości - jak wypowiedział się święty Sobór Powszechny Watykański II - kapłaństwo ze swej natury nie domaga się dziewictwa, jak to się okazuje z praktyki Kościoła pierwotnego i z tradycji Kościołów wschodnich (PO 16)" "3. W paragrafie 36 tej samej encykliki papież stwierdza, że obyczaj zachowywania celibatu przez duchownych wyższego stopnia Kościół zachodni „na początku IV wieku potwierdził, rozszerzył i uprawomocnił na różnych synodach prowincjalnych i przez usta papieży”. Z drugiej jednak strony w tej samej encyklice nr 19-25 papież Paweł VI wskazuje na Jezusa Chrystusa, prawdziwego kapłana, który sam żył w bezżeństwie i swoim przykładem wzywa do tego samego stylu życia tych, którzy uczestniczą w Jego kapłaństwie w sposób sakramentalny (Mt 19,12).

Także Jan Paweł II w adhortacji apostolskiej Pastores dabo vobis naucza, że „powołanie do celibatu i powołanie do kapłaństwa nie są ze sobą nierozerwalnie związane"4.

Do tego trzeba dodać odmienną praktykę Kościołów wschodnich, ustaloną podczas I Synodu Trullańskiego w Konstantynopolu w roku 691/92. Zgodnie z kanonami tego zgromadzenia, w Kościołach wschodnich celibat

${ }^{1}$ Por. A.M. Stickler, Il celibato ecclesiastico. La sua storia e $i$ suoi fontamenti teologici, Napoli 2010, s. 22-23.

${ }^{2}$ Sobór Watykański II, Dekret „Presbyterorum ordinis”, nr 16.

${ }^{3}$ Paweł VI, Encyklika ,Sacerdotalis caelibatus”, nr 17.

${ }^{4}$ Jan Paweł II, Adhortacja „Pastores dabo vobis", nr 29. 
zachowują jedynie biskupi, natomiast kapłani i diakoni mogą zawrzeć związek małżeński, jednak wyłącznie przed przyjęciem święceń ${ }^{5}$.

Pytania o sens celibatu kapłańskiego w Kościele katolickim wzbudził również list apostolski Ojca Świętego Benedykta XVI Anglicanorum coetibus o przyjęciu grup tradycyjnych anglikanów do Kościoła katolickiego, w którym zezwala się na święcenia żonatych anglikańskich diakonów, prezbiterów i biskupów. Jednak 9 listopada 2009 Stolica Apostolska wydała oświadczenie, że nie zmieni to praktyki Kościoła katolickiego w kwestii celibatu kapłańskiego ${ }^{6}$.

Ksiądz Grzegorz Ryś w swojej książce Celibat, mówiąc o początkach obowiązkowego bezżeństwa duchownych, stwierdza, że wynika on ze zmiany podejścia w Kościele zachodnim wobec ludzkiej cielesności, która nastapiła w II i III wieku: w miejsce postawy szacunku i dyskrecji, obecnej w Nowym Testamencie, zaczyna pojawiać się atmosfera podejrzliwości wobec ciała i płciowości, traktowanych teraz jako owoc i źródło grzechu. Tak twierdzili m.in. Orygenes, Tertulian, św. Justyn, św. Augustyn, św. Hieronim. Poglądy te, twierdzi ks. G. Ryś, wynikały z coraz większego wpływu gnozy i filozofii greckiej, zwłaszcza Platona, na chrześcijańską myśl i praktykę w kwestii pożycia małżeńskiego i w ogóle seksualności. Właśnie gnoza i platonizm, a nie Ewangelia, byłyby główną przyczyną wprowadzenia obowiązku celibatu duchownych w IV wieku, począwszy od Synodu w Elwirze (306). Ksiądz Ryś w swojej książce twierdzi, że celibat po IV wieku był narzucany przez papieży i biskupów wbrew woli duchownych i świeckich. Oznaczałoby to, że jest on nie tylko de iure humano, ale nawet, że jest poglądem quasi-manichejskim, który przeniknął do Kościoła u jego początków i z którym teraz się borykamy jako kłopotliwym dziedzictwem minionych wieków ${ }^{7}$.

Tymczasem A.M. Stickler podkreśla, że 33 kanon Synodu w Elwirze, który zakazuje wyświęconym biskupom, kapłanom i diakonom żyć z żonami i rodzić dzieci, nie jest nowym prawem, ale przypomnieniem tego, które istniało już wcześniej, lecz nie było przestrzegane. Nowością synodu jest nałożenie na tych, którzy nie przestrzegają prawa wstrzemięźliwości seksualnej po przyjęciu święceń, sankcji w postaci konieczności rezygnacji z urzędu duchownego. Podobne decyzje zapadły na Synodzie w Kartaginie w roku $390^{8}$.

\footnotetext{
${ }^{5}$ Por. Paweł VI, Encyklika ,Sacerdotalis caelibatus”, nr 38. Por. także: św. Tomasz z Akwinu, Summa teologiczna, t. 32, Matzeństwo, 53, 3 i 4, gdzie Doktor Anielski porównuje przepisy dotyczące celibatu w Kościele zachodnim i wschodnim.

${ }^{6}$ Por. La Costituzione per gli anglicani non altera il celibato nella Chiesa Latina, http://www.zenit.org/article-20258?l=italian, 09.11.2009 (dostęp: 15.10.2012).

${ }^{7}$ Por. G. Ryś, Celibat, Kraków 2004, s. 27-28. Także Wojciech Giertych OP stwierdza kategorycznie, że celibat nie należy do istoty kapłaństwa, http://mateusz.pl/list/0404giertych.htm (dostęp: 15.10.2012).

${ }^{8}$ Por. A.M. Stickler, Il celibato ecclesiastico, dz. cyt., s. 34-37.
} 


\section{Apostolskie pochodzenie celibatu duchownych}

Istnieje także inny, przeciwny pogląd na temat związku chrześcijańskiego kapłaństwa z celibatem. Przedstawiciele tej drugiej szkoły, tacy jak austriacki kardynał i historyk prawa kościelnego, A.M. Strickler, czy też Ch. Cochini ${ }^{9}$, R. Cholij ${ }^{10}$, egzegeta I. de la Potterie, S. Heid, twierdzą że celibat duchownych nie pojawił się dopiero w IV wieku Kościoła, ale pochodzi od samego Chrystusa i obowiązywał już w Kościele apostolskim. Jest on zatem pochodzenia boskiego - de iure divino.

Jakie argumenty przytaczają zwolennicy tej tezy na jej potwierdzenie?

Ksiądz Stefan Heid w wystapieniu wygłoszonym na Uniwersytecie Laterańskim podczas sympozjum z okazji Roku Kapłańskiego (11-12 marca 2010 r.) pt. Wierność Chrystusa, wierność kapłana starał się wykazać, że dzisiejszy celibat ma swoje korzenie w samych początkach chrześcijaństwa. Celibat, jako doświadczenie życia Kościoła w ciagu wieków, nie pojawił się nagle jako „ciało obce” lub jako sposób życia dobry jedynie dla pewnej epoki Kościoła. Nigdy nie został wprowadzony niejako z zewnętrz, ponieważ pochodzi z tradycji Kościoła apostolskiego ${ }^{11}$.

Punktem wyjścia dla S. Heida są odpowiedzi udzielone przez papieża Syrycjusza (384-399) na pytanie, które jego następcy, papieżowi Damazemu, postawił biskup Himeriusz z Tarragony. Na pytanie dotyczące obowiązku wstrzemięźliwości duchownych wyższych święceń papież odpowiedział w liście-dekrecie Directa (rok 385). W dokumencie tym po raz pierwszy, z pełną świadomością autorytetu nauczycielskiego, papież Syrycjusz mówi o obowiązku życia w stałej wstrzemięźliwości wszystkich duchownych wyższych święceń (biskupi, kapłani i diakoni) od dnia święceń. Osoby te muszą powstrzymać się od zawierania małżeństwa lub, jeśli byli żonaci, do pozostawienia swoich małżonek ${ }^{12}$.

\footnotetext{
${ }^{9}$ Por. Ch. Cochini, Origines apostoliques du celibate sacerdotal, Paris 1981.

${ }^{10}$ Por. R. Cholij, Clerical Celibacy in East and West, Herefordshire 1988.

11 Por. S. Heid, Il celibato ecclesiastico. Profili storico-ecclesiali, http://www. clerus.org/clerus/dati/2010-03/12-13/heid_it.html (dostęp: 17.10.2012); tenże, Celibat w Kościele pierwotnym. Początki obowiazku wstrzemięźliwości dla duchownych na Wschodzie i na Zachodzie, Tuchów 2000. Autor w swoich badaniach w dużej mierze opiera się na dziele Ch. Cochini, Origines apostoliques du célibat sacerdotal, Paris 1981; I. de la Potterie, Il fondamento biblico del celibato sacerdotale, http://www.paginecattoliche.it/modules.php? name $=$ News \&file $=$ article \&sid $=798$ (dostęp: 17.10.2012).

12 Por. S. Heid, Il celibato ecclesiastico. Profili storico-ecclesiali, dz. cyt. Heid stwierdza, że w Kościele pierwotnym istniały trzy grupy podejmujące wstrzemięźliwość ze względu na przyjęte święcenia wyższe: po pierwsze celibatariusze, którzy od swej młodości decydowali się na wstąpienie do stanu duchownego; następnie wdowcy, którzy nie mogli powtórnie zawierać związku małżeńskiego, jeśli chcieli zostać duchownymi; i po trzecie mężczyźni żonaci, których dzieci były już dorosłe. Ci po przyjęciu święceń byli zobowiązani do życia we wstrzemięźliwości, w „małżeństwie józefowym” lub w całkowitej separacji od żony. Dziś w Kościele rzymskokatolickim znamy przede wszystkim celibat nieżonatych mężczyzn, biskupów i kapłanów, ale Kościół pierwotny obligował do życia w celibacie wszystkich duchownych wyższych święceń (biskupów, kapłanów, diakonów), zarówno celi-
} 
W drugim liście papieża Syrycjusza, Cum in Unum z roku 386, skierowanym do biskupów Afryki, mowa jest o decyzjach podjętych na synodzie rzymskim z tego samego roku. Papież podkreślił w swoim liście, że decyzje dotyczące celibatu nie są nowymi obowiązkami, ale znanymi z tradycji punktami dyscypliny, które zostały jednak zaniedbane przez niektórych z powodu ich lenistwa, dlatego należy do nich wrócić i pilnie przestrzegać ${ }^{13}$.

Rodzi się pytanie, czy przepisy te zostały ustanowione przez papieża Syrycjusza, czy też sięgają wcześniejszej epoki? Stickler i Heid uważają, że Papież nie mógłby wymyślić a następnie narzucić Kościołowi tego rodzaju dyscypliny, jeśli nie miałaby ona pochodzenia apostolskiego. Czy jednak Papież i biskupi Hiszpanii, Galii i Afryki Północnej, którzy już wcześniej albo w tym samym czasie co Syrycjusz wydali dekrety o podobnej treści, mieli rację, powołując się na tradycję apostolską?

Według Syrycjusza wstrzemięźliwość duchownych miała charakter apostolski i obowiązkowy, a wynika ona $\mathrm{z}$ pism Nowego Testamentu, zwłaszcza z Listów Pasterskich św. Pawła. Chodzi mianowicie o Pierwszy List do Tymoteusza i List do Tytusa, które w trzech miejscach mówią o kandydatach do diakonatu, kapłaństwa i episkopatu. Paradoksalnie, w każdym z trzech fragmentów mówi się, że kandydat powinien być poślubiony ,,jednej żonie”, unius uxoris vir, tzn. może być żonaty tylko raz: 1 Tm 3,2: „Biskup więc powinien być nienaganny, mąż jednej żony”; $1 \mathrm{Tm}$ 3,12: „Diakoni niech będą mężami jednej żony”; Tt 1,6: prezbiterem może zostać ,jeśli ktoś jest nienaganny, mąż jednej żony" ${ }^{\prime 14}$. Czy zatem teksty te nie świadczą raczej

batariuszy, jak wdowców i żonatych, ponieważ to z tych trzech grup rekrutowali się duchowni (por. A.M. Stickler, Evoluzione della disciplina del celibato nella Chiesa d'Occidente dalla fine dell'età patristica al Concilio di Trento, w: Sacerdozio e celibato. Studi storici e teologici, red. J. Coppens, Milano 1975, s. 505-601). Autor stwierdza, że pod koniec pierwszych wieków chrześcijaństwa żonaci mężczyźni są dopuszczani do wszystkich stopni hierarchii z tym jednak, że przyjmując święcenia - przynajmniej od subdiakonatu - zobowiązują się do rezygnacji z małżeństwa, co zakłada obustronną zgodę małżonków. Kościół domaga się, by mąż, po ordynacji, zaprzestał zamieszkiwania ze swoją żoną lub też aby udzielił wystarczających gwarancji do zachowania obiecanej wstrzemięźliwości. Kto nie jest w stanie żyć we wstrzemięźliwości, powinien zrezygnować z wykonywania posługi, dla której został ordynowany. Po otrzymaniu święceń, subdiakon diakon, prezbiter ani biskup nie mogą zawierać małżeństwa (por. tamże, s. 506); (por. A. M. Stickler, Il celibato ecclesiastico, dz. cyt., 15-17).

${ }^{13}$ Por. A.M. Stickler, Il celibato ecclesiastico, dz. cyt., s. 45-46.

14 Por. H. Crouzel, Celibato e continenza ecclesiastica nella Chiesa primitiva: i motivi, w: Sacerdozio e celibato. Studi storici e teologici, dz. cyt., s. 451-504. Według tego autora, można zaobserwować ewolucję, stopniowe podwyższanie wymagań w Kościele pierwotnym wobec kandydatów do święceń wyższych: najpierw odrzucano prawie całkowicie święcenie tych mężczyzn, którzy ponownie się żenili po śmierci pierwszej żony i nie pozwalano na powtórne małżeństwo duchownych po ich owdowieniu. Następnie wszedł zakaz żenienia się po przyjęciu święceń wyższych. Wreszcie zobowiązano duchownego, który miał żonę w momencie święceń, do absolutnej wstrzemięźliwości. W Kościele wschodnim dotyczy to biskupa, w zachodnim od IV wszystkich duchownych począwszy od diakona (451). Zakaz ordynacji mężczyzn po drugim ślubie i małżeństw duchownych Ojcowie interpretowali jako spełnienie wskazówek z 1 Tm 3,2 (biskup mężem jednej żony) i 1 Tm 3,12 i Tt 1,6 (tak samo diakon i prezbiter) (por. tamże, s. 453). 
przeciw celibatowi duchownych? De la Potterie zauważa, że problem ten może zostać rozwiązany, jeśli pomiędzy dwoma punktami ekstremalnymi: celibatem i małżeństwem, znajdzie się punkt środkowy, a takim jest wstrzemięźliwość, do której zobowiązywali się duchowni żonaci ${ }^{15}$.

Z tekstów tych wynika, że jeśli kandydat do wyższych święceń był żonaty (chociaż nie było to konieczne), jego żona musiała być jego pierwszą żoną. Papież Syrycjusz wyjaśnia, że należy ten tekst rozumieć w ten sposób, że po przyjęciu święceń wszyscy powinni żyć we wstrzemięźliwości (propter continentiam futuram).

Sformułowanie „mąż jednej żony” oznacza zakaz powtórnego małżeństwa, także dla wdowców po przyjęciu ordynacji. Wynikało to z przekonania, że kto był żonaty (lub zamężny w przypadku wdów) po raz drugi, nie był w stanie żyć w doskonalej wstrzemięźliwości. Taka sytuacja wykluczała mężczyzn z przyjęcia wyższych święceń, a kobiety z przyjęcia do stanu wdów. Listy Pasterskie wskazuja, że każdy mężczyzna, który był w stanie żyć we wstrzemięźliwości i pragnął przyjąć wyższe święcenia, mógł być ordynowany. Przyjmowano, że mężczyzna żyjący w celibacie i wdowiec, który się powtórnie nie ożenił, byli zdolni żyć we wstrzemięźliwości. Jedynie dla mężczyzn żonatych, co zrozumiałe, sytuacja była inna. Przyjmowano jednak, że jeśli ktoś się decydował na przyjęcie święceń wyższych i na życie we wstrzemięźliwości, był to tego zdolny. Małżeństwo zawarte po raz drugi wskazywało natomiast, że nie był w stanie żyć we wstrzemięźliwości i taki człowiek nie był dopuszczany do święceń ${ }^{16}$.

Wstrzemięźliwość duchownych jako reguła kościelna istniała zatem o wiele wcześniej, niż została usankcjonowana kanonicznie. Papież Syrycjusz twierdzi, że celibat jako reguła opiera się na trzech podstawach: należy do tradycji apostolskiej, jest zgodny z Pismem Świętym i jest tradycją, której nie można usunąć.

${ }^{15}$ Por. I. de la Potterie, Il fondamento biblico del celibato sacerdotale, dz. cyt. Autor pisze, że termin unius uxoris vir nie jest stosowany wobec innych chrześcijan, ale tylko w kontekście wymagań wobec diakona, prezbitera i biskupa. Podobna zasada jest stosowana wobec wdowy, która, jeśli miała znaleźć się na „liście wdów”, musiała ona być unius viri uxor (1 Tm 5,9), ,żoną jednego męża”, miała mieć ukończony 60. rok życia i świadectwo, że służyła wspólnocie. Nie dotyczył zatem ten warunek każdej wdowy. Aby właściwie zrozumieć formułę unius uxoris vir jako argument za wstrzemięźliwością i celibatem, I. de la Potterie proponuje czytać ją w świetle 2 Kor 11,2: „Jestem bowiem o was zazdrosny Boską zazdrością. Poślubiłem was przecież jednemu mężowi, by was przedstawić Chrystusowi jako czystą dziewicę". Tu dziewicą i oblubienicą Chrystusa jest sam Kościół. Duchowni reprezentują Chrystusa, zatem powinni być poślubieni ,jednej żonie”, tj. Kościołowi. W podobnym duchu pisał Jan Paweł II w Pastores dabo vobis w nr 12, 22, 29: kapłan jest, na wzór Chrystusa - Oblubieńca Kościoła. Nr 29: „Kościół jako Oblubienica Chrystusa pragnie, aby kapłan miłował go w sposób całkowity i wyłączny, tak jak umiłował go Jezus Chrystus, Głowa i Oblubieniec”. Zatem formuła „mąż jednej żony” odnosi się również do mistycznych zaślubin diakona, kapłana i biskupa z Kościołem, na wzór Chrystusa.

${ }^{16}$ Por. G. Ryś, Celibat, dz. cyt., s. 2-21. Według ks. G. Rysia, papież Syrycjusz dokonał rewolucji w dotychczasowej interpretacji $1 \mathrm{Tm}$ 3,2-4 i 12 oraz Tt 1,5-6, obcej pierwotnemu duchowi tekstu. 
Heid wyciaga $\mathrm{z}$ tego wniosek, że celibat duchownych pochodzi z prawa Bożego, dlatego Kościół nie może z niego zrezygnować ${ }^{17}$. I. de la Potterie pisze, że praktyka celibatu pochodzi od samego Jezusa Chrystusa i Jego uczniów, dlatego wstrzemięźliwość u pierwszych chrześcijan była bardzo ceniona, jako naśladowanie stylu życia Jezusa i Apostołów (Mt 19,12). Obowiązek zaś celibatu, lub wstrzemięźliwości w przypadku mężczyzn żonatych, mimo że stał się prawem spisanym dopiero w IV wieku, to jednak od czasów apostolskich istniał jako prawo przekazywane ustnie i był uważany za najbardziej wskazany stan dla sług Kościoła ${ }^{18}$.

W tym kontekście S. Heid pisze o wypowiedzi Soboru Watykańskiego na temat celibatu duchownych obecnej w dekrecie Presbyterorum ordinis nr 16: „Doskonała i dozgonna powściagliwość, zalecana przez Chrystusa Pana ze względu na Królestwo niebieskie [...] nie jest wymagana jednak przez kapłaństwo z jego natury”. Według niego, słowa te należy rozumieć w ten sposób, że przez doskonata wstrzemięźliwość Sobór rozumie praktykę celibatu nieżonatych obecną w Kościele zachodnim. Nie mówi o wstrzemięźliwości duchownych, którzy są wdowcami, żonatymi lub nieżonatymi, jak to miało miejsce w pierwszym tysiącleciu. W tym, i tylko w tym sensie, można mówić, że aktualna dyscyplina dotycząca celibatu nie pochodzi z prawa Bożego i może zostać zmieniona. Kościół mógłby na nowo ordynować żonatych mężczyzn, ale ci po ich otrzymaniu musieliby żyć we wstrzemięźliwości, bowiem jako reguła kościelna pochodzi ona $z$ tradycji apostolskiej, co potwierdzali kapłani i biskupi z III i IV wieku. Z tego powodu nie może być zaniechana, zmianie mogą ulec jedynie jej konkretne formy jako dostosowanie się do nowej sytuacji.

${ }^{17}$ Por. L. Höd1, La lex continentiale. Studio sul problema del celibato, w: Sacerdozio e celibato. Studi storici e teologici, dz. cyt., s. 693-728. Na s. 716 autor zauważa, że lex continentiae stanowiona przez Kościół nie dawała, niestety, narzędzi do życia w doskonałej wstrzemięźliwości, np. brak było konkretnych przepisów na temat życia samotnego, dlatego wciąż na nowo pojawiały się problemy z łamaniem tego prawa. Dopiero reforma gregoriańska rozwiązała ten problem przez ustanowienie prawa o udzielaniu święceń wyższych tylko mężczyznom nieżonatym.

${ }^{18}$ Por. I. de la Potterie, Il fondamento biblico del celibato sacerdotale, dz. cyt.; M. Thurian, Mariage et célibat, Neuchatel 1964, s. 53-55, który, zanim jeszcze został księdzem katolickim, stwierdzał, że sam Chrystus nie żył w małżeństwie i Jego życie jest wystarczającym fundamentem dla życia w celibacie w naszych czasach. Celibat jest jednym ze znaków, które przypominają o absolutnych wymaganiach Chrystusa, o ustanowieniu Królestwa, konieczności bycia czujnym, zerwania ze światem. Nie jest się mniej człowiekiem przez życie w celibacie, tak jak Chrystus nie był nim mniej z tego powodu. Na temat znaczenia celibatu Chrystusa dla rozumienia misterium Jego osoby i dzieła oraz jako źródła celibatu w Kościele, por. także: A. Amato, Il celibato di Gesù, Città del Vaticano 2010; A.M. Stickler, Il celibato ecclesiastico, dz. cyt., 46. 


\section{MOŻLIWOŚCI OWOCNEGO PRZEŻYWANIA CELIBATU}

\section{Opinie psychiatrów}

W czasie, gdy w niemieckich mediach trwała kampania na temat pedofilii w Kościele katolickim (marzec-kwiecień 2010), zapytano austriackiego psychiatrę Raphaela Bonelii o celibat księży i jego związek z pedofilią. Bonelii stwierdził, że oburzenie z powodu pedofilii w Kościele byłoby mniejsze, gdyby nie celibat, który jest solą w oku społeczeństwa nastawionego na zabawę (homo ludens). Ten sposób życia pokazuje bowiem, że człowiek ze względu na większą miłość może zrezygnować z potrzeb seksualnych, a taka postawa jest dziś bardzo niepopularna. Gdyby księża byli żonaci, nie byliby inni, ksiądz byłby ,jednym z nas”.

Bonelii podkreślił, że celibatu nie można wyjaśnić pozna kontekstem wiary i odniesienia do Boga. We wszystkich wielkich religiach i kulturach są osoby, które wybierają bezżenność, zawsze były otaczane wielkim szacunkiem, np. w buddyzmie czy hinduizmie (np. Mahatma Gandhi, Dalai Lama). Także w Kościołach wschodnich, gdzie księża mogą się żenić, ci, którzy żyją w celibacie, są bardziej szanowani niż żonaci. Jeśli jednak duchowny żyjący w bezżeństwie nie kultywuje relacji miłości do Boga, karłowacieje w swoim człowieczeństwie lub nie wytrzymuje takiego sposobu życia. Aby kapłan dobrze przeżywał swój celibat, powinien przestać patrzeć na siebie i zaczać patrzeć na innych, na swoją relację z Bogiem i swoją posługę kapłańską. Problemy z czystością mają często ci, którzy za dużo czasu poświęcają na zajmowanie się sobą samym ${ }^{19}$.

Do podobnych wniosków dochodzi niemiecki teolog i psychiatra Manfred Lütz. W czasie wspomnianej już konferencji, która odbyła się w Rzymie na Uniwersytecie Laterańskim (11-12 marca 2010 r.), stwierdził, że z punktu widzenia społecznego i psychologicznego celibatariusz jest wyzwaniem, prowokacją. W świecie, w którym nie wierzy się już w życie i nagrodę po śmierci, ta forma życia jest protestem wobec banalizacji życia i powierzchowności. Celibat kapłański jest świadectwem, że ten świat z jego radościami i bólami nie jest wszystkim, jest wyznaniem wiary uczynionym nie za pomocą słów, ale jest on Credo wypowiedzianym własnym życiem. Jeśliby ze śmiercią wszystko się kończyło, celibat byłby nieporozumieniem, głupota. Dlaczego bowiem rezygnować z miłości kobiety i do kobiety, ze zrodzenia dzieci, z seksualności? Celibat ma sens tylko wtedy, jeśli istnieje życie wieczne, wtedy zapowiada on to, co ma dopiero nadejść. Dla naszego społeczeństwa celibat staje się „ościeniem dla ciała”, który wciąż na nowo przypomina, w porę i nie w porę, że troski związane z problemami życia na ziemi nie są wszystkim.

${ }^{19}$ Por. R. Bonelli, Manche Priester haben ein Beziehungsproblem mit Gott, www. katholisch-informiert.ch/2011/05/manche-priester-haben-ein-beziehungsproblem-mit-gott/ (dostęp: 20.10.2012). 
Lütz zauważa, że zazwyczaj „kryzys celibatu” jest poprzedzony kryzysem życia duchowego. Jeśli kapłan nie modli się regularnie, nie spowiada się, nie ma egzystencjalnej relacji z Bogiem, przestaje być płodny duchowo. To wystarczy, aby popaść w stan frustracji i niezadowolenia co do swego powołania kapłańskiego. Jeśli wtedy pojawi się możliwość nawiązania relacji zewnętrznej, istnieje poważne ryzyko, że tamy, już bardzo osłabione, zostaną przerwane. Celibat natomiast pozwala na nawiązywanie intensywnych kontaktów duszpasterskich. Przeżywany jedynie „zza biurka”, bez głębokich relacji duszpasterskich, jest z punktu widzenia psychologicznego trudny do owocnego przeżywania ${ }^{20}$.

\section{Wartość celibatu w ocenie teologów}

Jeśli chodzi o teologiczne znaczenie celibatu i czystości rozumianej jako ślub, o. Raniero Cantalamessa widzi jego potrójne znaczenie. Po pierwsze, celibat nosi w sobie wymiar prorocki, jako że jest znakiem królestwa Bożego, które ,już nadeszło" w osobie Chrystusa, ale wciąż czekamy na jego przyjście. Ponieważ królestwo Boże już przyszło, jest obecne w świecie, dlatego możliwe jest, że niektórzy wybiorą styl życia, jaki odpowiada ostatecznemu charakterowi królestwa. O życiu w królestwie Bożym Jezus mówi m.in. w Łk 20,34-36 (por. Mt 22,30): „Dzieci tego świata żenią się i za mąż wychodzą. Lecz ci, którzy zostaną uznani za godnych udziału w świecie przyszłym i w powstaniu z martwych, ani się żenić nie będą, ani za mąż wychodzić. Już bowiem umrzeć nie mogą, gdyż są równi aniołom i są dziećmi Bożymi, będąc uczestnikami zmartwychwstania”. Dlatego właśnie celibat jest profetycznym stylem życia ${ }^{21}$. Po drugie, celibat i dziewictwo mają wymiar misyjny. Ponieważ królestwo Boże ,jeszcze nie" nadeszło, dlatego trzeba kobiet i mężczyzn, którzy poświęcą się, by je głosić i mogą to czynić, mając serce niepodzielnie oddane Oblubieńcowi, jako ci, którzy troszczą się „o sprawy Pana” (1 Kor 7,31-35). Po trzecie wreszcie, dziewictwo nosi w sobie także wymiar ofiary i wyrzeczenia, ponieważ królestwo Boże w osobie Chrystusa zawisło na krzyżu, jak uczy św. Paweł w Flp 2,8-1122.

${ }^{20}$ Por. M. Lütz, Il celibato ecclesiastico. Profili psico-spirituali, http://www.zenit.org/ article-21716?1=italian (dostęp: 20.10.2012).

${ }^{21}$ Por. R. Cantalamessa, Czystego serca, Warszawa 1994, s. 18.

${ }^{22}$ Por. tamże, s. 23-43; L. Höd1, La lex continentiale, dz. cyt., s. 727-728, gdzie autor w podsumowaniu stwierdza, że wstrzemięźliwość jest zarazem cnotą moralną i darem łaski, charyzmatem. Należy do sfery rad ewangelicznych, prawa kościelnego i osobistej decyzji. Realizuje się poprzez rezygnację z małżeństwa i życie w doskonałej czystości. Wyraża gotowość do służby Chrystusowi i do służby ludowi Bożemu, corpus Christi verum et mysticum. Wstrzemięźliwość gwarantuje skoncentrowanie na czymś jednym i wyższym, wskazuje na życie ludzkie, które jest in statu viatoris, w pielgrzymce do nieba. Taki styl życia potrzebuje łaski i codziennej ascezy. Kościół uznał ten sposób życia za najlepszy dla duchownych, odwołując się do Mt 19,12, 1 Kor 7,25, a przede wszystkim do przykładu życia Chrystusa Pana i Maryi Dziewicy. 
$\mathrm{Na}$ temat sposobu przeżywania celibatu kapłańskiego wypowiedział się podczas rzymskiego sympozjum Wierność Chrystusa, wierność kapłana nigeryjski biskup Fortunatus Nwachukwu. Mówiąc o duchowości celibatu, bp Fortunatus porównuje jego przeżywanie do postu. Doskonała czystość jest bowiem związana z samoograniczeniem się, z abstynencją. Oznacza to, że celibat, czystość i dziewictwo są rodzajem trwałego postu. Wskazują na wyrzeczenie się czegoś, co byłoby godne i upragnione, oznaczają umartwienie i ofiarę. W przypadku postu, jego przedmiotem nie może być coś, na co nie mam ochoty, apetytu, czego nie lubię. Ktoś, kto nie pali, nie może wybrać abstynencji od tytoniu, podobnie jak ktoś, komu nie smakują słodycze, nie może „pościć”, nie jedząc ich. Analogicznie, jedynie osoby zdolne do aktywności seksualnej mogą podjać praktykę celibatu kapłańskiego.

Porównanie celibatu z postem może sugerować, że celibat byłby stylem życia jedynie pełnym wyrzeczeń, smutnym, a przecież w swej istocie jest stylem życia pełnym sensu, ponieważ pozwala poświęcić się całkowitej służbie Chrystusowi i braciom i w pełni upodobnić się do Chrystusa. Post jednak nie ma jedynie wymiaru negatywnego, nie jest równoznaczny z brakiem, ubóstwem niezależnym od nas. Jest także dobrowolnym działaniem podjętym w celu osiagnięcia większych dóbr, duchowych lub fizycznych.

Analogia z postem pozwala lepiej zrozumieć, w jaki sposób przeżywać celibat kapłański. W Nowym Testamencie mamy teksty przytaczane na potwierdzenie celibatu, czystości i dziewictwa (por. Mt 19,11-12; Łk 18,29-30; 1 Kor 7,33-35), jednak żaden z nich nie mówi, w jaki sposób go przeżywać. Natomiast Pismo Święte mówi, w jaki sposób przeżywać post, aby był owocny. Przez analogię, można zastosować wskazówki podane przez Chrystusa co do przeżywania postu do celibatu kapłańskiego.

Najważniejszy jest tu tekst z Mt 6,1-18. „Trylogia” Jezusa odnośnie praktykowania pobożności, która wspiera się na trzech filarach: modlitwie, jałmużnie i poście. Te trzy praktyki wskazują na trzy relacje: do siebie samych (post), do Boga (modlitwa) i bliźniego (jałmużna). Post pomaga panować nad apetytem i wzmaga samodyscyplinę, odsuwa uwagę od nas samych (od własnych potrzeb, pragnień, pożądań, głodów) i przenosi ją na Boga i bliźniego. W ten sposób sprawia, że stajemy się dyspozycyjni wobec Boga i bliźniego. Zatem post (tzn. akty negacji siebie, jak śluby ubóstwa, czystości i posłuszeństwa) bez modlitwy (otwarcia na Boga) i jałmużny (otwartość na bliźniego) nie tylko jest pusty i nieznaczący, ale może oznaczać hipokryzję i sadyzm lub w najlepszym przypadku akt pychy i duchowości na pokaz. Natomiast kiedy post staje się podstawą modlitwy i miłosierdzia, otwiera na Boga i bliźniego.

Jakie wynikają z tego wnioski dla przeżywania celibatu kapłańskiego?

Podobnie jak w przypadku postu, celibatowi powinny towarzyszyć modlitwa i miłość, które otwierają kapłana na Boga (modlitwa) i drugiego człowieka (caritas). Kiedy ich brak, celibat zaczyna oznaczać skupienie się na sobie samym i łatwo zamienia się w rodzaj hipokryzji i pychy. Wzrasta 
arogancja i brak cierpliwości dla bliźniego, zwłaszcza wobec tych, którzy wydają się nie dostrzegać znaczenia celibatu. Celibat właściwie przeżywany powinien w sercu kapłana stworzyć przestrzeń, którą wypełni modlitwa, czyli obecność Boga, i miłość bliźniego. Rzeczywiście, post bez miłości jest bezowocny, jak mówi św. Paweł: „Gdybym wydał ciało swoje na spalenie, a miłości bym nie miał, nic bym nie zyskał" (1 Kor 13,3). Post i celibat mają pomóc sprawić, by człowiek umarł sobie i wydał owoc, jak ziarno pszenicy, które wpadnie w ziemię (por. J 12,24) na wzór Jezusa, który, będąc w pełni i w sposób doskonały człowiekiem, żył w bezżeństwie, pościł, był kuszony, cierpiał i umarł, by zmartwychwstać w chwale ${ }^{23}$.

\section{ZAKOŃCZENIE}

Celibat duchownych w Kościele katolickim dla wielu jest „,solą w oku” i „kamieniem obrazy”, prawem, które należałoby jak najszybciej usunąć. Jego znaczenie jest tym łatwiej zrozumieć, im większą jest świadomość, że kapłan jest przez sakrament święceń włączony w Chrystusa - Kapłana i Dobrego Pasterza, którego powinien naśladować we wszystkich aspektach Jego życia i działania, aby określenie alter Christus było nie tylko słowem, ale i rzeczywistością. Dlatego papież Jan Paweł II w adhortacji posynodalnej Pastores dabo vobis tak pisał: „Szczególnie ważne jest, by kapłan zrozumiał teologiczną motywację kościelnego prawa o celibacie. Prawo jako takie wyraża wole Kościoła, która jest wcześniejsza niż wola podmiotu wyrażona poprzez gotowość. Zaś wola Kościoła znajduje swoją ostateczną motywację w zwiqzku, jaki łaczy celibat ze święceniami kapłańskimi, które upodabniają kapłana do Jezusa Chrystusa, Głowy i Oblubieńca Kościoła. Kościół jako Oblubienica Chrystusa pragnie, aby kapłan miłował go w sposób całkowity i wyłączny, tak jak umiłował go Jezus Chrystus, Głowa i Oblubieniec. Celibat kapłański jest więc darem z siebie w Chrystusie i z Chrystusem dla Jego Kościoła i wyraża posługę kapłana dla Kościoła w Chrystusie i z Chrystusem"24.

${ }^{23}$ Por. F. Nwachukwu, Celibato, castità, verginità, http://www.clerus.org/clerus/ dati/2010-03/12-13/Fortunatus_it.html (dostęp: 20.10.2011).

${ }^{24}$ Jan Paweł II, Adhortacja Pastores dabo vobis, nr 29. 


\section{HISTORICAL AND SPIRITUAL ASPECTS OF THE CELIBACY IN THE CHURCH}

\section{Summary}

The purpose of this article is to show two views on the origin of a celibacy for a religious reason in the Catholic Church. The first one which results from the law, and the second one that has divine roots in which the source of such a life is Jesus Christ himself and his disciples. In the second part of the article there are some psychiatrists' and theologians' opinions about the possibilities of a mature priestly celibacy life.

Keywords:

chastity, celibacy 